Easter does not fall on April 25, as given by the formula, but on April 18.

These exceptions are caused by an inconsistency in the Gregorian rule, caused by the adherence to the old custom, that Faster should never fall later than April 25.

Armagh Observatory, June 22.

J. L. E. Dreyer.

Tine discrepancy between the date of Easter, 1954, April 18 as given by the tables in the Book of Common Prayer, and April 25 as given by the formula of Gauss, arises from a purely artificial contrivance of Clavius, who arranged the reformed calendar, which is thus described on p. 55 of "The Prayer Book Interleaved," 1873 , in an account of the calendar founded on a paper by Prof. De Morgan :-" It will never happen as to mean lunations, and rarely as to real ones, that in the same cycle there should be the lunation of a given month beginning on the same day in two different years of the cycle; and such a thing never happened in the unreformed Calendar. Clavius thought it desirable to imitate this in the new Calendar; and he observed that by takings the preceding day whenever the Epact was xxv., and the year of the cycle after the 1 ith, he could avoid the reiteration, and thus make the desired resemblance." "Whenever the Epact should be xxv., the year of the cycle being upwards of $I 1$, say that the Epact is 26. This is not an astronomical correction, but a mere conventional mode of reconciling the choice which Clavius made of the mode of writing the Epacts with an essential peculiarity of the old cycle of I9 years which that mode of writing would have otherwise destroyed." "In 195t the Golden Number is 17 . the Sunday letter $\mathrm{C}$, and the Epact according to the ordinary rule, xxv. Call it therefore xxvi. Thence April if will be the 14th day of the Paschal Moon, April r8, Easter Day. If the Epact xxv. were used April 25 would be Faster Dav." The paper by Prof. De Morgan will be found in the "Companion to the British Almanac" for 1845 .

Iy copy of Natere for April 5 has long since gone to Bolivia, but probably your correspondents will find that Gauss did not take into account this artifice of Clavius. If in this century golden number 6 and Sunday letter $C$ had coincided, Easter would have been set on April 25 , because 6 comes in the cycle before 11 instead of after it as 17 does. An inspection of Table III. for finding Easter will show in the two half-lines for April 17 and 18 the arrangement made by Clavius.

Banwell Vicarage, June 22.

\section{Musical Thunder.}

Farty this morning a storm broke in this neighbourhood accompanied by heavy thunder. During the storm I noticed that two of the peals began with a musical note of distinct and definite pitch. The "musical" portion of the peal lasted for about two seconds in each case, and the frequency of the note was both times about 400 per second.

This sound closely resembled a foot-fall in a narrow alley between high walls, and was only heard in two consecutive peals, separated by an interval of about a minute, the first being much niore definitely musical than the second. In each case the interval between the flash and the first sound of thunder was about five seconds.

As is well known, a peal of thunder from lightning near at hand frequently sounds like a quick succession of raps or a volley of guns. Can the successive raps have followed one another so rapidly in this case that they combined to form a note?

If so, and if this note was due to a special configuration of reflecting surfaces in the clouds, postibly to others in slightly different positions, considerably different frequencies may have been observed.

The fact that two peals only sounded in this manner separated by the short interval of about one minute, and that the second was not so decidedly musical as the first, seems to indicate that they were due to some rapidly changing source such as one might expect the reffecting surfaces of a cloud to be. I listened carcfully to deter- mine that the note had its origin outside and was not due to resonance within the room, and in the second peal it was certainly outside, and probably had the first had its origgin within the room I should have observed it.

I should be very glad, to hear if anyone has observed a similar phenomenon.

G. H. MaRTYN.

I Marden Road, S. Tottenham, N., June 24.

\section{How do Inquiline Bees find the Nest of their Host?}

TuE following observation may serve to throw light on the above question, which has doubtless occurred to many entomologists. Yesterday I saw a specimen of the inquiline Coelioxys quadridentata enter the burrow of a leaf-cutter bec, Megachile circumcincta. I dug the nest out of the burrow', and in so doing scattered the sand over an area of several square inches, completely destroyinz all appearance of a burrow. I sat down to await the return of the Megachile, in order to identify the species, and w:is much astonished to see (and capture) in the course of the next ten minutes two more specimens of Conlioxys, which came hovering over the spot and alighted on the disturbed soil. I can think of no other explanation than that these "cuckoos" were attracted to the spot by the scent of the excavated nest. I may add that during several hours spent on the heath where this occurred I saw no other sperimens of Coelioxys, and, further, that there was a fresh south-east breeze blowing at the time, and that the bees came up against the wind.

Charterhouse, Godalming, June 24 .

\section{OSWILD H. I,ATTER.}

\section{THE IISTURBANCE OF GREENWICH OBSERIATIONS:}

I $N$ the House of Lords on Thursday last, June 2 I, attention was directed to the threatened danger to the continued efficiency of the Royal Observatory, Greenwich, caused by the great electrical generating station erected by the I.ondon County Council about half a mile due north of the observatory. The danger $r$ was referred to by the Astronomer Royal in his report to the Board of Visitors on May 30 , a summary of which appeared in NaTCke of June 7 (p. 135). "The? generating station is situated exactly in the Greenwich meridian, as will be seen from the accompanying photograph of a view looking north over the top of the transit room; and the tall chimneys shown in the picture, as well as the heated air from them, will obviously interfere with some observations of northern stars, which are essential for latitude and refraction. Moreover, from tests already made it appears that the powerful engines which are being installed at the generating station will cause vibrations that will seriously affect the value of observations by reflection from a mercury horizon, required for the fundamental work of the observatory.

This is not the first time that the effects of generating stations and electric tramway systems in the neighbourhood of the observatory have been pointed out. About six years ago the question of the possible effect of disturbances from electric railways on the magnetic work carried on at the observatory was griven careful consideration; and the hope was th"n expressed that in the event of future electric tramwars regulations would be laid down by the Board of Trade to secure adequate protection for the magnetic work. The records in this department of the observatory have been obtained continuously on a general system for sixty-five years, but the astronomical work extends over more than two centuries and a quarter, and it would be unfortunate if circumstances should arise to break this chain of continuity.

The generating station established at Deptford nearly a mile from the observatory-to supply the London County Council Tramways with electric No. I9I 3 , VOL. 74? 